\title{
STRATEGI PROMOSI FESTIVAL DESA WISATA PADANG KANDIS OLEH DINAS PARIWISATA KABUPATEN BELITUNG
}

\author{
Helen Olivia ${ }^{1}$, Widarti ${ }^{2}$ \\ Universitas Satya Negara Indonesia, helenolivia.fisip@gmail.com \\ Univeristas Bina Sarana Informatika, widarti.wdr@bsi.ac.id
}

\begin{abstract}
Abstrak
Abstrak - Penelitian ini membahas tentang bagaimana Dinas Pariwisata Kabupaten Belitung menerapkan strategi promosi dalam kegiatan festival desa wisata. Tujuan dari penelitian ini adalah mendeskripsikan implementasi strategi promosi festival desa wisata. Teori yang digunakan adalah Integrated Marketing Communications (IMC). Paradigma yang digunakan adalah konstruktivisme dan metode penelitian kualitatif digunakan. Metode yang digunakan adalah studi kasus. Topik penelitian dalam penelitian ini meliputi penyedia informasi kunci dan penyedia informasi. Gunakan teknik pengumpulan data wawancara dan observasi. Hasil penelitian menunjukkan bahwa strategi promosi berupa word of mouth dan public relations yang disesuaikan dengan kondisi pedesaan dan karakteristik budaya lokal.
\end{abstract}

Kata Kunci: Strategi Promosi, Pariwisata, Komunikasi Pemasaran

\begin{abstract}
Abstract - This study discusses how the Belitung Regency Tourism Office implements promotional strategies in tourism village festival activities. The purpose of this research is to describe the implementation of the promotion strategy of the tourism village festival. The theory used is Integrated Marketing Communications (IMC). The paradigm used is constructivism and qualitative research methods are used. The method used is a case study. Research topics in this research include key information providers and information providers. Use interview and observation data collection techniques. The results showed that the promotion strategy in the form of word of mouth and public relations was adapted to rural conditions and local cultural characteristics.
\end{abstract}

Keywords: Promotion Strategy, Tourism, Marketing Communication

\section{PENDAHULUAN}

Desa wisata dikenal sebagai objek wisata yang memadukan antara tempat wisata, fasilitas umum, fasilitas wisata dan lingkungan bebas pembatas, serta menghadirkan tatanan kehidupan masyarakat yang memadukan kesamaan adat dan tradisi. Salah satu bentuk integrasi antara tempat berpemandangan indah, akomodasi dan fasilitas penunjang yang terwujud dalam tatanan kehidupan masyarakat yang terintegrasi dengan tata cara dan tradisi terkini. Mengacu pada industri pariwisata yang terdiri dari pengalaman pedesaan, pemandangan alam, dan elemen tradisional unik yang dapat menarik seluruh wisatawan. Pengembangan desa wisata keberadaan desa wisata menjadi sangat penting. karena membuat destinasi kawasan wisata menjadi berwarna, sehingga industri pariwisata tidak selalu terjebak oleh tren perkembangan pariwisata massal.

Wisatawan dapat menikmati keindahaan alam tempat wisata dengan segala fasilitasnya dan keleluasaan berwisata berinteraksi langsung dengan lingkungan dan masyarakat lokal. Perubahan ini mendorong muculnya konsep pariwisata pedesaan ditandai dengan munculnya desa-desa wisata di berbagai provinsi di Indonesia (Suyanti, 2013). Desa wisata dikemukakan oleh Suyanti (2013) sebagai suatu bentuk lingkungan yang memiliki ciri khusus, baik alam maupun budaya yang sesuai dengan tuntutan wisatawan, di mana mereka dapat menikmati, mengenal, menghayati dan 
mempelajari fitur desa beserta segala daya tariknya.

Desa Wisata Padang Candice ditetapkan sebagai desa wisata dengan jenis wisata budaya dan seni serta produk berkualitas tinggi antara lain kerajinan tangan, seni budaya, pertanian, perkebunan, lukisan dan masakan tradisional. Berbagai potensi wisata di Desa Padang Candice sudah tidak diragukan lagi. Diantara 42 desa wisata yang ditetapkan oleh Kabupaten Belitung, Desa Padang Kandis merupakan desa / kelurahan yang menjadi landmark wisata Kabupaten Belitung. Desa Padang Kandis memiliki produk yang sangat beragam, diantaranya berbagai petunjuk, seperti cara mengemas mekanisme penambangan dengan wisata perkebunan, makanan lezat masakan tradisional (seperti nanas yang diolah menjadi sirup dan bongkahan), hasil pertanian dan perkebunan (seperti madu Trigona kemasan) dan berbagai kesenian khas Belitung lainnya.

Dalam konteks pariwisata, pengembangan desa wisata merupakan bagian tak terpisahkan dari naik turunnya pembangunan pariwisata. Di desa wisata, industri pariwisata membuktikan posisinya dengan semangat menyerap tenaga kerja pedesaan, mendorong pertumbuhan ekonomi daerah, dan mengurangi kemiskinan. Dalam mengembangkan desa wisata, perlu diadakan kegiatan promosi untuk menarik wisatawan. Kegiatan promosi adalah kegiatan intensif yang dilakukan dalam waktu yang relatif singkat. Dalam promosi ini dilakukan upaya untuk meningkatkan daya tarik produk pariwisata kepada calon konsumen. Konsumen tidak membudayakan dan kebutuhannya, tetapi produknya lebih sesuai dengan kebutuhan konsumen. Untuk melakukan promosi yang tepat, harus disadari bahwa yang dialokasikan ke pasar biasanya bukan produk jadi, melainkan hanya komponen-komponen berikut ini: inn, objek wisata, dan transportasi.

Komponen yang masih perlu di remix agar menjadi produk paket wisata yang lengkap. Produk dapat dirakit oleh wisatawan yang bepergian. Inti dari produk pariwisata adalah destinasi pariwisata. Inilah yang menjadi daya tarik pariwisata. Destinasi adalah suatu tempat atau wilayah yang memiliki kelebihan dan karakteristik baik secara geografis maupun budaya, sehingga dapat menarik wisatawan untuk berkunjung dan menikmatinya. Semua produk yang terkait dengan perjalanan sebelum, selama dan setelah destinasi merupakan produk yang menunjang industri pariwisata. Produk-produk ini bersatu dan tidak dapat dipisahkan untuk menciptakan pengalaman yang "memuaskan" bagi wisatawan.

Berdasarkan latar belakang diatas perlu adanya strategi promosi festival desa wisata padang kandis untuk meningkatkan dan mengembangkan pariwisata desa. Maka, penulis tertarik untuk melakukan penelitian dengan judul Strategi Promosi Festival Desa Wisata Padang Kandis Oleh Dinas Pariwisata Kabupaten Belitung. Sedangkan tujuan penelitian adalah Untuk mendeskripsikan pelaksanaan strategi promosi festival desa wisata.

\section{Strategi}

Strategi adalah konsep yang mengacu pada jaringan kompleks pemikiran, konsep, pemahaman mendalam, pengalaman, tujuan, keterampilan, ingatan, persepsi, dan harapan.Jaringan ini memandu pengembangan kerangka kerja secara keseluruhan sehingga kita dapat menentukan tindakan tertentu untuk dicapai tujuan kita, strategi tidak terlepas dari tujuan yang dicapai. Hal ini ditunjukkan adanya jaringan yang dapat memandu tindakan yang akan dilakukan, dan strategi akan mempengaruhi tindakan tersebut. Artinya, prasyarat yang diperlukan untuk mengembangkan strategi adalah meningkatkan pemahaman tentang tujuan. Artinya setelah kita memahami hakikat dan makna tujuan bersama, kita telah menentukan strategi untuk mencapai tujuan tersebut. Tanpa tujuan, tindakan 
yang dilakukan hanyalah strategi yang dapat meningkat pesat, tetapi akan merosot menjadi masalah lain (Liliweri, 2011: 239)

\section{Promosi}

Promosi merupakan salah satu variabel dalam bauran pemasaran yang sangat penting untuk diterapkan perusahaan dalam memasarkan produk jasa. Kegiatan promosi tidak hanya menjadi sarana komunikasi antara perusahaan dengan konsumen, tetapi sebagai alat yang mempengaruhi pembelian atau penggunaan jasa sesuai dengan kebutuhan dan pengaruh konsumen (Lupiyoadi dan Hamdani, 2011: 120). Menurut Indriyo Gitosudarmo (2008: 285), promosi adalah "suatu kegiatan yang dirancang untuk mempengaruhi konsumen agar mereka terbiasa dengan produk yang diberikan perusahaan kepada mereka, kemudian mereka menjadi bahagia, kemudian membeli produk tersebut". Menurut (Philip Kotler, 2008), "Promosi mencakup semua alat dalam bauran pemasaran walikota berdasarkan komunikasi persuasif". Dapat disimpulkan bahwa promosi adalah agen pemasaran perusahaan untuk menginformasikan dan mempengaruhi orang atau pihak lain yang tertarik pada suatu transaksi atau pertukaran barang atau jasa yang dipasarkan. Macam media komunkasi di Indonesia seperti : Surat kabar, Televisi, Radio, Majalah, Buletin, Brosur, Telepon dan Internet.

\section{Integrated Marketing Communication (IMC)}

Integrated

Marketing

Communications, atau Integrated Marketing Communications (IMC) dikenal sebagai "Quadruple" (American Association of Advertising Agencies), adalah konsep rencana komunikasi pemasaran yang mengakui nilai tambah dari suatu rencana komprehensif yang mengkaji masing-masing peran strategis dari periklanan formal, seperti periklanan, pemasaran langsung, promosi, dan hubungan masyarakat, dapat digabungkan untuk mencapai kejelasan, konsistensi dan dampak komunikasi yang maksimal melalui integrasi yang maksimal (Sulakasana, 2003: 30). Pekerjaan ini mengindikasikan bahwa setiap pesan yang dikirim harus berasal dari sumber yang sama sehingga semua informasi diumumkan oleh perusahaan memiliki tema dan situasi yang sama dimata konsumen.

Hermawan mendefinisikan IMC sebagai proses mengelola sumber informasi tentang produk / layanan. Dalam proses ini, pelanggan dengan proses didorong oleh: Mendorong proses dengan cara tertentu untuk mendorong perilaku mereka untuk mencapai penjualan dan membangun loyalitas konsumen. Singkatnya, komunikasi pemasaran terintegrasi adalah rencana, tindakan, dan koordinasi terpadu di bidang komunikasi pemasaran untuk memahami cara konsumen benar-benar menanggapi konsumen. Metode IMC dapat membantu perusahaan menentukan metode yang tepat dan efektif untuk berkomunikasi dan menjalin hubungan dengan pelanggan mereka dan pemangku kepentingan lainnya (seperti karyawan, pemasok, investor, kelompok kepentingan, dan publik). .

$$
\text { Kotler \& Keller (2010:197) }
$$

menjelaskan komunikasi pemasaran terintegrasi dapat menghasilkan konsistensi pesan yang lebih kuat dan membantu membangun ekuitas merek dan menciptakan dampak penjualan yang lebih besar. IMC memaksa manajemen memikirkan semua cara pelanggan berhubungan dengan perusahaan, bagaimana perusahaan mengkomunikasikan posisinya, masalah ketepatan waktu, dan arti relatif setiap sarana. Komunikasi pemasaran terintegrasi harus meningkatkan kemampuan perusahaan untuk menjangkau pelanggan yang tepat dengan pesan yang disampaikan tepat. 


\section{Bauran Komunikasi pemasaran}

Menurut Priansa (2017: 98), perusahaan kini menyadari perlunya mengintegrasikan berbagai kegiatan komunikasi pemasaran yang telah dilakukan secara terpisah. Perusahaanperusahaan ini mulai bergerak menuju proses yang disebut Integrated Marketing Communications (IMC), yang meliputi koordinasi berbagai elemen promosi dan aktivitas pemasaran lainnya. Elemen promosi dan pemasaran lainnya tersebut disebut dengan bauran komunikasi pemasaran yang terdiri sebagai berikut:

\section{Periklanan (advertising).}

Iklan dapat digunakan untuk membangun citra produk berjangka panjang. Menurut Wells, Burnet, Moriarty (2000:175) iklan didefinisikan komunikasi nonpersonal yang dibayar oleh sponsor dengan menggunakan massa untuk membujuk atau memperkenalkan sponsor kepada pelanggannya.

Boone Kurtz (2010:174) menyatakan iklan mengacu pada komunikasi nonpribadi yang dibayar, yang pada umumnya ditargetkan untuk pembeli potensial dalam jumlah yang besar. Iklan menjadi peran penting dalam promosi bukan hanya memberikan informasi kepada khalayak tetapi ditujukan untuk mempengaruhi perasaan, citra, kepercayaan, citra produk yang bik biasanya tercipta melalui kegiatankegiatan periklanan. (Widyatama, 2005:78).

Menurut Shimp (2010:178) iklan dapat dikategorikan menurut tujuan spesifiknya, yaitu memberikan informasi, membujuk, mengingatkan.

a. Iklan informatif umumnya dianggap sangat penting untuk peluncuran produk baru, menjelaskan manfaat produk,

b. Iklan persuasif sangat penting apabila mulai tercipta tahap persaingan, tujuan iklan adalah membangun kinerja merek

c. Iklan yang bertujuan mengingatkan (reminder advertising) menjaga produk itu untuk tetap diingat pembeli,penting untuk produk yang sudah dewasa, dan membuat konsumen terus mengingat produk tersebut

\section{Pemasaran langsung (direct marketing)}

Pemasaran langsung adalah sistem pemasaran yang memungkinkan perusahaan dan atau pemasar untuk berkomunikasi secara langsung dengan pelanggan mereka untuk menghasilkan tanggapan atau transaksi langsung. Robert (2008: 112) mengemukakan bahwa pemasaran langsung adalah kegiatan pemasaran moneter yang bertujuan untuk mendapatkan tanggapan dari calon pelanggan melalui komunikasi telepon, surat, email atau faks. Perkembangan era yang selalu berubah ini mendorong perusahaan untuk menggunakan berbagai media pemasaran langsung yang tersedia bagi para pemasar, antara lain: media massa, internet, dan media sosial. Menurut Kotler dan Amstrong (2012: 108), manfaat pemasaran langsung dapat menghemat banyak waktu, memperkenalkan konsumen pada lebih banyak pilihan produk, dan memberikan diskon.

\section{Promosi penjualan (sales promotion)}

Perusahaan menggunakan alat promosi dan kompetisi kupon untuk menarik tanggapan pembeli yang lebih cepat dan lebih cepat, termasuk efek jangka panjang seperti menjelaskan produk dan mengurangi penjualan. Cravens and Piercy (2013: 122) menunjukkan bahwa promosi mencakup berbagai kegiatan promosi, antara lain pameran dagang, kompetisi, sampel / sampel, dan kupon. Biaya promosi lebih besar daripada biaya iklan dan sama dengan biaya staf penjualan. Promosi Buchari Alma (2014: 123) mengemukakan bahwa tujuan promosi biasanya untuk menarik pelanggan baru, memberikan hadiah atau reward kepada pelanggan, mencegah pelanggan menggunakan produk merek lain, meningkatkan upaya pembelian kembali pelanggan, mempromosikan merek / 
meningkatkan loyalitas, dan meningkatkan penjualan.

4. Hubungan masyarakat (public relations) Jika sebuah perusahaan secara sistematis merencanakan dan mendistribusikan informasi untuk mengontrol dan mengelola citranya serta publisitas yang diterimanya, itu artinya perusahaan tersebut menjalankan tugas kehumasan (PR) yang erat kaitannya dengan manajemen sasaran. Untuk mencapai dan menyesuaikannya dengan lingkungan. Kotler dan Amstrong (2012:164) menyatakan bahwa hubungan masyarakat meliputi berbagai program yang dirancang untuk mendukung atau melindungi citra organisasi bisnis atau produk organisasi bisnis tersebut. Fungsi humas yaitu: Kegiatan yang bertujuan memperoleh kepercayaan, dan citra yang baik dari public, Menciptakan hubungan yang harmonis antara organisasi bisnis dan publiknya, Hubungan dengan pers yakni menyajikan berita dan informasi, Konseling yaitu memberi saran manajemen tentang isu-isu publik dan bagaimana perusahaan menyikapi, Publisitas produk seperti mensponsori berbagai program, Menarik perhatian terhadap produk baru atau kegiatan pemasaran dengan menyelenggarakan peristiwa khusus.

5. Pemasaran dari mulut ke mulut Strategi word of mouth merupakan strategi yang dapat memberikan pengaruh terbaik terhadap pengambilan keputusan konsumen saat mengkonsumsi barang atau jasa. Melalui pemasaran dari mulut ke mulut, informasi negatif atau negatif tentang barang dan jasa Ma dengan cepat menyebar dari satu orang ke orang lain. Pemasaran ini dapat berbentuk online dan offline. Hasan (2010: 340) mengemukakan bahwa word-of-mouth marketing merupakan sumber informasi yang kuat yang mempengaruhi keputusan pembelian, karena sumber informasi yang jujur dan independen membawa manfaat bagi mereka yang bertanya secara

langsung tentang pengalaman produk.

\section{Pemasaran interaktif}

Pemasaran saat ini mengalami perubahan oleh kemajuan teknologi komunikasi yang memungkinkan komunikasi secara interaktif melalui media masa, yaitu internet. Media interaktif memungkinkan terjadinya arus informasi timbal balik yang memungkinkan pengguna dapat berpartisipasi.

\section{Pengertian desa wisata}

Desa wisata mengacu pada pengembangan suatu kawasan desa yang pada dasarnya tidak merubah desa yang ada, tetapi lebih cenderung mengembangkan potensi desa yang ada dengan memanfaatkan fungsi unsur-unsur yang ada di desa sebagai atribut produk pariwisata. Dapat dibagi menjadi rangkaian kegiatan atau kegiatan pariwisata, serta dapat menyediakan dan memenuhi rangkaian kebutuhan pariwisata (termasuk atraksi dan fasilitas penunjang) (AJ, Muljadi, 2012).

\section{Kategori desa wisata}

Menurut Antara Made dan I Nyoman Arinda, desa wisata dibagi menjadi dua kategori, yaitu:

a. Desa wisata yang sedang berkembang, desa yang memiliki potensi wisata, dapat dikembangkan menjadi desa wisata, dan sudah ada gerakan masyarakat / desa untuk mengelolanya sebagai desa wisata.

b. Mengembangkan desa wisata Desa wisata yang sedang berkembang yang dikelola oleh masyarakat dan pemerintah desa sudah memiliki kemandirian masyarakat / desa, sudah mulai melakukan kegiatan promosi, dan wisatawan sudah tertarik.

Desa wisata tingkat tinggi, desa wisata yang dikembangkan melalui kunjungan forum profesional, telah membentuk forum pengelolaan, seperti koperasi / badan usaha desa (BUMdes) yang selanjutnya disebut 
BUMdes, serta dapat melakukan promosi dan pemasaran dengan baik.

\section{Karaktersitik Desa Wisata}

Setiap desa wisata tentunya memiliki karakteristik tersendiri hal tersebut dilihat dari adanya potensi di desa tersebut sehingga layak untuk dijadikan sebagai desa wisata. Pengelolaan suatu desa wisata sebagai objek wisata tidak hanya terbatas pada penetapannya sebagai desa wisata. Penetapan suatu desa sebagai desa wisata setidaknya didasarkan atas beberapa komponen potensial yang mendukung, yaitu: 1. Adanya atraksi atau daya tarik yang khas dari desa itu sendiri. 2. Adanya fasilitas-fasilitas dan akomodasi pariwisata seperti fasilitas penginapan, fasilitas makan-minum, pusat jajanan atau cenderamata, pusat pengunjung. 3. Adanya aktifitas wisata seperti menenun, menikmati pemandangan dan lainlain. 4 . Adanya pengembangan umum sebagai upaya untuk menciptakan daerah tujuan wisata yang memberikan pelayanan terbaik bagi wisatawan, diantaranya: pembagian zona atau area, pengelolaan pengunjung, dan pelayanan komunikasi (Anthonius Ibori, 2013).

\section{METODOLOGI PENELITIAN}

Paradigma yang digunakan dalam penelitian ini adalah paradigma konstruktivis. Paradigma konstruktivis merupakan paradigma yang hampir menempatkan observasi dan objektivitas pada lawan pemahaman dalam penemuan realitas atau sains. Paradigma ini memandang ilmu sosial sebagai analisis sistematis dari tindakan bermakna dalam masyarakat dengan pengamatan langsung dan rinci dari aktor sosial yang terlibat dalam menciptakan dan memelihara atau mengelola dunia sosialnya (Dedy $\mathrm{N}$, Hidayat, 2003). Metode penelitian yang digunakan adalah kualitatif, karena digunakan untuk mendeskripsikan implementasi strategi promosi desa wisata. Diperlukan teknik observasi (observasi) dan wawancara mendalam (in-depth interview).Metode penelitian yang digunakan dalam penelitian ini adalah studi kasus. Menurut studi kasus Bimo Walgito (2010), metode ini bertujuan untuk mempelajari dan menyelidiki kejadian atau fenomena yang berkaitan dengan individu, seperti riwayat hidup subjek. Bimo Walgito juga menambahkan bahwa untuk memperoleh informasi yang lebih mendalam tentang metode studi kasus yang diterapkan, perlu banyak informasi dan integrasi data dari metode lain.

\section{Key Informan dan informant}

Key Informan yang telah memenuhi kriteria diatas adalah H. Sahani Saleh selaku Bupati Belitung. Sedangkan informantnya adalah Jasagung Hariyadi selaku Kepala Dinas Pariwisata Kabupaten Belitung, Ibu Zulyanti selaku pelaku UMKM.

\section{Teknik Pengumpulan Data}

Berdasarkan sumber datanya, pengumpulan data dapat menggunakan sumber primer dan sekunder. Teknik pengumpulan data utama dalam penelitian ini dilakukan melalui wawancara mendalam dan observasi. Sedangkan data sekunder dari penelitian ini diperoleh melalui studi pustaka dan studi pustaka.

\section{Teknik Analisis Data}

Teknologi analisis data menggunakan model proses analisis data Miles dan Huberman, yang meliputi tiga tahapan (Sugiyono, 2010: 91). Pertama reduksi data yaitu meringkas dan memilih data dasar yang penting, kemudian membuat kategori. Kedua, representasi data (data display), yaitu merepresentasikan data dalam bentuk yang lebih terstruktur dan berpola. Terakhir, verifikasi atau tarik kesimpulan.

\section{Teknik Keabsahan Data}

Dalam penelitian ini, penulis menggunakan metode triangulasi sumber untuk meringkas data hasil penelitian 
secara sistematis (termasuk wawancara, karyawisata dan referensi lainnya), serta menganalisis data yang diperoleh penulis dari berbagai sumber, dan dilakukan perbandingan sehingga dibuat perbandingan. data yang diperoleh akurat dan mudah dirangkum kepada khalayak untuk mendapatkan informasi.

\section{HASIL DAN PEMBAHASAN}

Dalam kegiatan promosi akan berlangsung proses komunikasi. Dalam kegiatan publisitas Desa Wisata Padang Kandis, unsur komunikasi dilibatkan yaitu yang pertama adalah unsur komunikator dimana Dinas Pariwisata berperan sebagai komunikator, Dalam publisitas Desa Wisata Padang Kandis, pelaku UMKM adalah komunikatornya. Akhirnya menjadi komunikator saat menerima balasan pesan promosi. Sebagai unsur komunikasi kedua, pesan tersebut berisi materi promosi desa wisata Padang Kandis dengan ikon-ikon antara lain perkebunan, pertanian dan produk masakan tradisional. Informasi promosi ini dikomunikasikan oleh manajemen yang bertindak sebagai lembaga pelaksana promosi atau sumber informasi lainnya, seperti Kelompok Sadar Wisata Padang Candice (POKDARWIS). Selain itu, media yang digunakan sebagai elemen ketiga untuk penyampaian pesan promosi meliputi saluran komunikasi non media, seperti komunikasi tatap muka dan word of mouth. Dan melalui saluran komunikasi seperti radio, surat kabar, dan situs web.

Ditinjau dari tujuan komunikasi pemasaran Desa Wisata Padang Candice yaitu tahap pembentukan kesadaran, strategi komunikasinya adalah perubahan pengetahuan. Pada tahap ini, penggunaan media yang paling tepat adalah media massa yang mampu menarik banyak penonton. Salah satu bentuk promosi yang menggunakan media ini adalah periklanan. Padahal, di lapangan, Dinas Pariwisata Kabupaten Belitung tidak menggunakan jenis promosi ini. Hal ini dikarenakan biaya periklanan yang sangat besar dan anggaran yang masih terbatas.Selain itu, media yang digunakan sebagai elemen ketiga untuk penyampaian pesan promosi meliputi saluran komunikasi non media, seperti komunikasi tatap muka dan word of mouth. Dan melalui saluran komunikasi seperti radio, surat kabar, dan situs web. Ditinjau dari tujuan komunikasi pemasaran Desa Wisata Padang Candice yaitu tahap pembentukan kesadaran, strategi komunikasinya adalah perubahan pengetahuan. Pada tahap ini, penggunaan media yang paling tepat adalah media massa yang mampu menarik banyak penonton. Salah satu bentuk promosi yang menggunakan media ini adalah periklanan. Padahal, di lapangan, Dinas Pariwisata Kabupaten Belitung tidak menggunakan jenis promosi ini. Hal ini dikarenakan biaya periklanan yang sangat besar dan anggaran yang masih terbatas. Selain itu, media yang digunakan sebagai elemen ketiga untuk penyampaian pesan promosi meliputi saluran komunikasi non media, seperti komunikasi tatap muka dan word of mouth. Dan melalui saluran komunikasi seperti radio, surat kabar, dan situs web. Ditinjau dari tujuan komunikasi pemasaran Desa Wisata Padang Candice yaitu tahap pembentukan kesadaran, strategi komunikasinya adalah perubahan pengetahuan. Pada tahap ini, penggunaan media yang paling tepat adalah media massa yang mampu menarik banyak penonton. Salah satu bentuk promosi yang menggunakan media ini adalah periklanan. Padahal, di lapangan, Dinas Pariwisata Kabupaten Belitung tidak menggunakan jenis promosi ini. Hal ini dikarenakan biaya periklanan yang sangat besar dan anggaran yang masih terbatas. Dari seluruh strategi promosi efektif yang ada, Dinas Pariwisata Kabupaten Belitung belum memperhatikan elemen terakhir, yakni mengintegrasikan bauran promosi (Integrated Marketing Communication atau IMC).

\section{Periklanan (advertising).}

Iklan yang digunakan dalam festival desa wisata ini memang yang paling efektif 
adalah iklan diradio. Hal ini digunakan dikarenakan sebagain besar masyarakat kabupaten Belitung mendengarkan radio sebagai sumber informasi. Iklan diradio dilakukan oleh Dinas Pariwisata dalam menyampaikan program-programnya tertutama mempromosikan kegiatan tahunan seperti festival desa wisata yang sudah dilakukan. Promosi melalui radio bisa dijangkau oleh semua kalangan sehingga bisa menarik kunjungan yang lebih besar.

\section{Pemasaran langsung (direct marketing)}

Pemasaran yang dilakukan oleh Pelaku UMKM dalam memasarkan produknya sifatnya langsung. Masih sedikit pelaku UMKM ini dalam mengelola produknya yang menggunakan media online dalam memasarkan produknya. Hanya media Whatsapp yang digunakan sebagai media promosi di wilayah Padang Kandis ini.

\section{Promosi penjualan (sales promotion)}

Dalam mempromosikan produknya para pelaku UMKM tidak memberikan diskon atau prmosi yang besar-besaran dikarenakan produk yang dijual merupakan produk unggulan yang diproduksi sendiri tanpa menggunakan bantuan alat teknologi seperti mesin dan lain-lainnya, sehingga produk yang dijual pun masih dengan harga yang cukup murah dan bisa dijangkau oleh masyarakat Belitung maupun pengunjung dari luar Belitung.

\section{Hubungan masyarakat (public relations)}

Dalam hal ini, Dinas Pariwisata Kabupaten Belitung didukung oleh Kementerian Pariwisata dan Ekonomi Kreatif RI dalam mengembangkan seluruh program khususnya bagian pengembangan pariwisata. Dinas Pariwisata Belitung juga didukung oleh para travel agent yang memang menjadi potensi positif untuk menarik jumlah wisatawan yang datang ke Belitung dan berkunjung ke setiap acara yang sudah menjadi acara tahunan.
Kerjasama dengan pihak terkait juga seperti hotel dan akomodasi yang memudahkan para wisatawan menikmati perjalanan wisatanya. Untuk publikasi kegiatan, pihak Dinas Pariwisata Kabupaten Belitung juga mengemas dalam bentuk digitalisasi yang di kemas dengan baik melalui media online seperti Youtube, Facebook serta publikasi di media cetak dan radio. Ini dilakukan untuk menunjang promosi agar para wisatawan bisa membawa anggota lainnya untuk berkunjung ke Belitung.

\section{Pemasaran dari mulut ke mulut}

Strategi dari mulut ke mulut merupakan strategi yang memberikan pengaruh besar bagi keberlangsungan kegiatan yang dilaksanakan. Strategi ini tidak memerlukan biaya yang besar tapi memberikan efek yang baik bagi promosi. Pemasaran ini menjadi tolak ukur ketika masyarakat menikmati kegiatan ini. Pada strategi ini dimana strategi yang efektif untuk dilakukan oleh semua pihak. Mereka mampu memberikan informasi yang baik dan positif atas sesuatu yang dilihatnya sehingga mampu mempengaruhi keputusan seseorang untuk datang dan menikmati festival kegiatan ini.

\section{Pemasaran interaktif}

Perkembangan teknologi komunikasi yang dapat digunakan melalui media massa (surat kabar) dan internet akan mendukung pemasaran ini. Namun yang sering digunakan adalah menggunakan radio sebagai media interaktif. Radio hanya sebatas memberikan informasi dan bukan interaksi aktif. Oleh karena itu, seiring dengan kemajuan teknologi, bukan berarti masyarakat tidak menerima informasi, tetapi media offline memungkinkan masyarakat untuk menerima kekurangan terutama pada media online dan interaktif.

Padahal, elemen terakhir ini sangat penting dalam agenda promosi. IMC akan memungkinkan audiens target untuk menerima pesan yang konsisten, terintegrasi dan tersinkronisasi. IMC 
melibatkan kombinasi berbagai teknologi dan media komunikasi untuk meningkatkan pengetahuan dan pemahaman konsumen tentang produk atau layanan. Berdasarkan bentuk kombinasi promosi yang dilakukan oleh Dinas Pariwisata Kabupaten Belitung terlihat tidak semua elemen digunakan dalam jadwal promosi Desa Wisata Padang Candice. Dalam segala bentuk promosi, fokus utama promosi adalah melalui hubungan masyarakat dan pemasaran dari mulut ke mulut.

\section{KESIMPULAN}

Berdasarkan uraian yang disampaikan sebelumnya, kesimpulan dapat diambil dari hasil penelitian. Dinas Pariwisata Kabupaten Belitung belum merumuskan strategi promosi yang komprehensif dan komprehensif. Meski begitu, kegiatan promosi tetap dilakukan. Kegiatan promosi tersebut memiliki beberapa tujuan yang ingin dicapai, antara lain untuk meningkatkan kesadaran, menambah pengetahuan, dan mengingatkan masyarakat tentang Desa Wisata Padang Candice dan potensi wisatanya terutama hasil perkebunan, pertanian dan kuliner. Tujuan berkunjung ke desa wisata Padang Kandis berbeda-beda tergantung tujuan belanja, penelitian / penelitian atau penelitian komparatif. Jika ditentukan berdasarkan wisatawan selama ini, target audiens Desa Wisata Padang Kandis meliputi mahasiswa dan mahasiswa, tamu pemerintah dan negara, instansi / perusahaan, media dan masyarakat.

Kegiatan promosi yang belum masuk dalam rencana kerja Biro Pariwisata menyebabkan kurangnya perhatian pada desain berita. Isi informasi dakwah biasanya masih tersebar dalam bentuk konsep moral, penyampaian informasi tentang Desa Wisata Padang Candice. Sumber beritanya tidak hanya dari Dinas Pariwisata, Dinas Pariwisata Kabupaten Belitung, tetapi juga secara tidak langsung terlibat dalam transmisi informasi tentang Desa Wisata Padang Candice. Dinas
Pariwisata

Kabupaten

Belitung

menggunakan berbagai media dalam menyebarkan informasi promosi. Secara garis besar media ada dua jenis, yaitu saluran komunikasi non media dan saluran komunikasi media.

Saluran komunikasi non media yang digunakan adalah komunikasi tatap muka dan dari mulut ke mulut. Melalui media tersebut, Biro Pariwisata telah melakukan kegiatan promosi. Beberapa bentuk kombinasi promosi sedang dilaksanakan termasuk periklanan, pemasaran langsung, promosi, hubungan masyarakat, pemasaran dari mulut ke mulut dan interaktif. Sarana promosi lain yang terjadi secara tidak langsung adalah dari mulut ke mulut. Diantara semua bentuk promosi yang dilakukan oleh Dinas Pariwisata, fokus utama promosi adalah dari mulut ke mulut dan kehumasan.

\section{DAFTAR PUSTAKA}

Bimo, Walgito, Pengantar Psikologi Umum (Yogyakarta: CV Andi, 2010)

Boone, Louis E dan Kurtz, David L, Pengantar Bisnis Kontemporer. Terjemahan Anwar Fadriansyah (Jakarta: Erlangga, 2010)

Buchari, Alma, Manajemen Pemasaran Dan Pemasaran Jasa (Bandung: Alfabeta, 2011)

Cravens, D.W, Piercy N.F, Strategic Marketing, 10th Editi (Singapore: McGraw-Hill Companies, Inc, 2013)

Dedy N, Hidayat, Paradigma Dan Metodologi Penelitian Sosial Empirik Klasik (Jakarta: Departemen Ilmu Komunikasi FISIP Universitas Indonesia, 2003)

Hasan, Ali, Marketing (Yogyakarta: MedPress, 2010)

Hermawan, Agus, Promosi Dalam Prioritas Kegiatan Pemasaran (Jakarta: PT Buku Seru, 2013)

Ibori, Anthonius, 'Partisipasi Masyarakat Dalam Pelaksanaan Pembangunan Di Desa Tembuni Distrik Teluk Bintuni', Governance, 5.1 (2013)

Indriyo Gitosudarmo, Manajemen 
Pemasaran, edisi pert (Yogyakarta: BPFE, 2008)

Kotler, P. \& Keller, K.L., Manajemen Pemasaran Jilid I, Edisi ke 1 (Jakarta: Erlangga, 2012)

Kotler, P, Keller K.L, Marketing Management, 14 th edit (England: Person Education, Inc, 2012)

Liliweri, Alo, Komunikasi Serba Ada Serba Makna. Cetakan Ke-1 (jakarta: Kencana, 2011)

Lupiyoadi, Rambat dan Hamdani A, Manajemen Pemasaran Jasa (Jakarta: Salemba Empat, 2011)

Muljadi, A.J, Kepariwisataan Dan Perjalanan (Jakarta: PT Raja Grafindo Persada, 2012)

Priansa, Junni Donni, Perilaku Konsumen Dalam Bisnis Kontemporer (Bandung: Alfabeta, 2017)

Slavin, Robert E, Cooperative Learning: Teori, Riset Dan Praktik (Bandung: Nusa Media, 2008)

Sugiyono, Metode Penelitian Pendidikan Pendekatan Kuantitatif, Kualitatif, $R \& D$ (Bandung: Alfabeta, 2010)

Sulaksana, Integrated Marketing Communications; Teks Dan Kasus (Yogyakarta: Pustaka Pelajar, 2003)

Suyanti, Dewi Winarni, 'Potensi Desa Melalui Pariwisata Perdesaan', Ekonomi Dan Bisnis, 1.12 (2013), 3336
Terence, A Shimp, Periklanan Promosi Komunikasi Pemasaran Terpadu (Jakarta: Erlangga, 2006)

Wells, William, John Burnett, and Sandra Moriarty, Advertising: Principles Dan Practise. Fifth Edition. Upper Sadle River (New Jersey: PrenticeHall International Inc., 2000)

Widyatama, Rendra, Pengantar Periklanan (Jakarta: Buana Pustaka Indonesia, 2005)

\section{BIODATA PENULIS \\ Helen Olivia, S.Ikom., M.Ikom}

Dosen di Universitas Satya Negara Indonesia. Menyelesaikan jenjang pendidikan Strata Satu (S1) di Universitas Prof. Dr. Moestopo (B) Jakarta Tahun 2007. Fakultas Ilmu Komunikasi Jurusan Ilmu Komunikasi (Humas) dan menyelesaikan Strata Dua (S2) Magister Komunikasi Korporat Tahun 2012. Selain aktif mengajar juga aktif sebagai narasumber $\mathrm{PR}$, moderator, $\mathrm{MC}$ untuk kegiatan seminar politik komunikasi, menghandle event dan peneliti komunikasi.

\section{Widarti, M.I.Kom}

Dosen di Universitas Bina Sarana Informatika Program Studi Periklanan dan anggota tim PPPM UBSI. 